\title{
AFFECT AND INTERACTION IN \\ AN AMBIGUOUS AUTHORITY \\ RELATIONSHIP
}

New Zealand's Bureaucrats and

the Ombudsman

\author{
LARRY B. HILL \\ University of Oklahoma
}

One of the Ombudsman's characteristics which commands the attention of students of political power and bureaucracy is the institution's effectiveness despite minimal coercive capabilities. ${ }^{1}$ Unlike the newer versions, the Swedish and Finnish Ombudsmen have the primarily vestigial authority to prosecute administrators. The essence of the modern institution is the Ombudsman's ability to investigate citizens' complaints and recommend that bureaucratic decisions be altered. Making such a recommendation is ordinarily the most "negative situational sanction" the most "severe deprivation" with which the Ombudsman can threaten a department. Many theorists would consider this to be his strongest and perhaps only source of "power" (see Parsons, 1963: 90; Lasswell and Kaplan, 1952: 76). Thus, the Ombudsman must

AUTHOR'S NOTE: This article, which is part of a much larger study
entitled "The International Transfer of Political Institutions: A
Behavioral Analysis of the New Zealand Ombudsman" (Ph.D. disserta-
tion, Tulane University, 1970) is revised from a paper presented at the
Annual Meeting of the Southern Political Science Association, Novem-
ber 11-13, 1971. Research support was provided by a Fulbright 
establish a positive relationship with the bureaucrats whom he superintends.

This paper reports upon an investigation of the character of this relationship for the New Zealand Ombudsman, who was adopted in 1962. The New Zealand official was given the essential ingredients of the Danish version, and he was the first non-Scandinavian Ombudsman. His success provided the initial evidence that the institution was not dependent upon a uniquely Scandinavian constellation of cultural and political factors. Because of the New Zealand officer's relative longevity, which provides necessary historical perspective, and because he has been the primary model for subsequent Ombudsmen, as well as for the plethora of proposals, this first Anglo-Saxon Ombudsman is particularly worthy of study. ${ }^{2}$

The substantive aspects of the relationship treated here include the perceptual context of the Ombudsman-departmental nexus; a measurement of the bureaucrats' psychosocial distance from the Ombudsman; perceptions of the Ombudsman's impact upon the public service; evaluation of the Ombudsman's jurisdiction; and general affect for the Ombudsman.

\section{METHODOLOGY}

Between May 1967 and August 1968, I personally interviewed the permanent or department heads (permanent secretaries in British parlance) of the following nineteen government departments, ranked according to frequency of

Fellowship to New Zealand in 1966-1968. I am indebted to the many New Zealand public officials who consented to be interviewed and to Sir Guy Powles, the New Zealand Ombudsman, who has contributed so much to his own investigation. In addition, John Roberts and Don McAllister, my former colleagues at the Victoria University of Wellington, provided various kinds of assistance. William B. Gwyn of Tulane University commented usefully upon an earlier draft. 
complaints against them to the Ombudsman; the figure after each is the number of complaints recorded in the Ombudsman's Report for 1967: Social Security 438, Inland Revenue 212, Education 177, Customs 142, State Services Commission 130, Health 122, State Advances Corporation 112, Labor 112, Works 107, Justice 106, Police 95, Post Office 90, Railways 82 , Superannuation 70 , Agriculture 28, Transport 28, Treasury 14, External Affairs 9, Government Printer, 1.

The first thirteen were chosen because their departments were those against which there had been the most complaints. The six additions were chosen either because their departments also had substantial experience with the Ombudsman, because their departments were for other reasons intrinsically important, or because they were particularly well regarded as experienced and knowledgeable public servants. Usually more than one reason was operable.

A subsidiary purpose of the investigation was to determine if the department's extent of interaction with the Ombudsman affected the respondent's perceptions of him. It was arbitrarily decided that respondents whose departments had more than 100 complaints against them would be dubbed "high interactors" while those having fewer would be "low interactors." Thus, approximately equal subgroups of ten and nine, respectively, were created. Because of the small cells often created, the subsequent analysis usually reports differences only when they are clearly delineated.

The interviews were usually at least an hour in length and ranged from about forty-five minutes to two and one-half hours. The strategy used was to attempt to postpone the scheduled interview with the permanent head until other junior officers-usually those who actually handled the flow of work with the Ombudsman and other appeals agents-had been interviewed, relevant files had been examined, and reports and the like had been collected. Sometimes, however, this was not possible when a minister's secretary or another 
permanent head scheduled the next appointment so close that there was little time for preliminaries. The dual reasoning behind the strategy was that this procedure would make it easier to interpret and sometimes even to check the truth of replies to questions; therefore, it was an attempt to increase the interviewer's credibility. It was hypothesized that a permanent head might respond differently to an interviewer whom he knew had already done considerable research in his department than to one whom he might regard as an ignorant American with a long list of tiresome and possibly irrelevant questions.

\section{THE PERCEPTUAL CONTEXT}

Before exploring the parameters of the permanent heads' orientations toward the Ombudsman, it is necessary to set the scene. Specifically, the relationship between the bureaucracy's administrative values and those of the Ombudsman must be probed. Furthermore, structural and attitudinal aspects of the Ombudsman's rank require investigation.

\section{SHARED VALUES}

Talcott Parsons (1968: 437) has proclaimed: "The most important single condition of the integration of an interaction system is a shared basis of normative order." Prior to the appointment of the Ombudsman, New Zealand's civil service was conceded to be efficient, and such values as honesty, fairness, equality, justice, and the like were widely distributed. Certainly, nothing even approaching the celebrity of Britain's (mild by American standards) Crichel Down scandal of 1954 had been suggested in New Zealand. The Ombudsman was established not to alter the value system but to supplement the already existing value-maintaining agents. One indication of the extent to which these values are shared 
can be found in the department heads' responses to the following attitude statement: "As one of the effects of modern government, we have to expect that not every grievance can be remedied." Sixteen (84\%) disagreed, and none strongly agreed with it.

Another question's results provide further insights: "How would you evaluate the possible agencies open to the citizen with a complaint against the government? First, what do you think is the most effective action the citizen can take?" This was not a difficult question for them to answer. Fifteen (79\%) volunteered that appealing to the department itself was the citizen's most effective recourse. The following quotations are representative:

- We rectify genuine grievances that come to us. There is no profit in doing something stupid or wrong.

- You must expect errors in a department such as ours when we have thousands of daily contacts with the public. We make them right.

- What the citizen should always do is to go to the local office where the decision was made and ask for a hearing; it will be disposed of there.

- If we have done a man an injustice in one of our offices-this is almost always at the lowest level-why, we ought to be given the first chance to correct it.

Conflicts between departments and the Ombudsman do not arise over competing values, but rather over competing interpretations of how to implement the shared values. Although such competition may sometimes become fairly intense, the "subjective psychological costs of compliance" (Dahl, 1963: 43) with the Ombudsman are low; this basic congruence of values is an important and perhaps vital component of the Ombudsman's authority. 


\section{HIERARCHICAL AMBIGUITY}

The Ombudsman stands outside the traditional flow of authority which stems downward from the minister, through the permanent head, into the department at large. Although he interposes himself into that traditional relationship, his power does not extend to the nullification of administrative decisions. He may only recommend changes; this puny power, which is not at all congruent with his sweeping warrant for investigations, may be appealed by the department to their minister, the prime minister, and, ultimately, to Parliament. $^{3}$

It would be surprising if the Ombudsman's structurally ambiguous position were not reflected in the department heads' perceptions. Perceived rank, which correlates highly with willingness to respect an authority figure (see Hopkins, 1964: 157-182), was probed by the following open-ended question: "What are your ideas on the Ombudsman's true position in the political system? How important is he as compared with some other officials, such as a Supreme Court Judge, the Solicitor-General, an M.P., a Minister, a Department Head?"

It is clear from the replies that the Ombudsman is highly respected, and he was compared to a Supreme Court Judge-an eminently respected official in New Zealand-more often than to any other. Although many respondents were fascinated by the question, and several mulled it over at length, most were unable to formulate an answer! These replies were characteristic: "It's difficult to define; he's a very different type." "He's unique; I don't know who to compare him to," or "Well, he must fit in somewhere, but it's hard to say just where," Thus, the fact that the Ombudsman and New Zealand bureaucrats share basic norms would seem to predispose them toward perceptions and actions favorable to him. However, the structural and attitudinal ambiguities of his authority cloud those expectations. 


\section{MEASUREMENT OF BUREAUCRATS' PSYCHOSOCIAL DISTANCE FROM OMBUDSMAN}

The concept of social distance attempts to measure "grades and degrees of understanding and intimacy" (see Goode and Hatt, 1952: ch. 16). The usual measurement technique is a scale which defines an affective continuum. However, the existing scales were inappropriate, and it did not prove feasible to develop a scale which could measure the bureaucrats' social distance from the Ombudsman. Instead, three individual questions investigated this dimension.

\section{INCIDENCE OF THOUGHTS OF OMBUDSMAN}

The first inquired:

"In your day-to-day work how often would you say you have occasion to think of the Ombudsman?"

\begin{tabular}{ccccc}
$\begin{array}{c}\text { Very } \\
\text { Seldom }\end{array}$ & $\begin{array}{c}\text { Sometimes } \\
\text { on Cases }\end{array}$ & $\begin{array}{c}\text { When He } \\
\text { Writes }\end{array}$ & Often & Total \\
\hline $57 \%(11)$ & $16 \%(3)$ & $16 \%(3)$ & $11 \%(2)$ & $100 \%(19)$
\end{tabular}

Eleven replied that they very seldom thought of him. One said, "Never! Except in 1966 when I took over, I rang him up and assured him of my cooperation." Another assured the interviewer, "He's no concern to us at all." A senior head said, "To be perfectly frank, I don't think of him. I'm a lawyer and in our training we get a lot of ethics." It is interesting that $70 \%$ of the high interactors contended that they seldom or never thought of the Ombudsman as compared with only $40 \%$ of the low interactors. This appears to be a classic instance of the defense mechanism of displacement.

Three respondents said they sometimes thought of him in dealing with specific cases as the following quotations indicate: 
Only a month ago a case came up, a staff matter; I said, if we decide it this way and he takes it to the Ombudsman, we won't have a leg to stand on.

About six times a year. I usually think of him when I explain to a junior member of the staff why something isn't on.

Three others said they thought of him only in connection with the work they had to do to answer his letters; one of them said that he only thought of the Ombudsman at the moment he signed his officers' replies. Only two claimed to think of him often.

\section{DISPOSITION OF OMBUDSMAN'S REPORTS}

The next question was:

$$
\begin{gathered}
\text { "What do you do about the Ombudsman's } \\
\text { Annual Reports?" }
\end{gathered}
$$

\begin{tabular}{lccc}
$\begin{array}{l}\text { Nothing in } \\
\text { Particular }\end{array}$ & $\begin{array}{c}\text { Check for } \\
\text { Reported } \\
\text { Performance }\end{array}$ & $\begin{array}{c}\text { Objects to } \\
\text { Scorekeeping }\end{array}$ & Total \\
\hline $36 \%(7)$ & $32 \%(6)$ & $32 \%(6)$ & $100 \%(19)$
\end{tabular}

Subsequent probes made it clear that the objective was to gather a variety of reactions to the Reports. Seven of the respondents had no apparent interest in them; as would be expected, six of them were low interactors. One said, "They're water under the bridge, why should I be interested?" Another replied that he had not seen the most recent Report (then six months old) and said, "You've got it there in your bag, let's see how we did." However, the remaining $64 \%$ did look at the Reports. Six of them said they checked their rating with him; one specifically mentioned that while he read them he did not send them out to his officers: "They are not waiting with bated breath for the 
result." Another took just the opposite view and circulated them in all the district offices: "It's good to familiarize them with situations of complaint. He has wasted a lot of our time, but that's all part of the caper." Six others (five were high interactors) regularly scrutinized the Reports and also objected to the Ombudsman's scorekeeping of "justified" cases. For example, one fumed, "This score is inflated, because most of these people hadn't complained to us first. I am sensitive to this because I want it to be known that we do what is right."

\section{PERSONAL KNOWLEDGE OF OMBUDSMAN}

Twelve of the department heads were asked the final social distance question, "Do you know Sir Guy Powles personally?" Of those, seven said they did, and three of them said they knew him prior to his appointment. One had worked in the same law firm with him at the beginning of their careers. Only two flatly said that they did not know him. Three others who did not feel that they knew Sir Guy personally said they had met him. One of them commented that he occasionally met Sir Guy at cocktail parties, and they made small talk without really talking about their jobs. Thus, the majority of those asked felt that they had at least some personal linkage with the Ombudsman.

\section{THE OMBUDSMAN'S PERCEIVED IMPACT UPON THE PUBLIC SERVICE}

According to the Ombudsman's most recent Report (for 1967) at the time interviewing began, his impact upon the government departments would appear to be quantitatively minor. An analysis of the Report reveals that, even for the high interactors, a mean of only 17.5 cases per department had been classified "considered justified" from the Ombuds- 
man's inception in 1962. The mean was only 5 cases per department for the low interactors. Of course, these few cases may have been considered quite important by the departments, or they may have been sorely irritated by his other investigations which were classified as "not justified," "declined," "discontinued," or "withdrawn." The analysis turns to the Ombudsman's perceived impact upon the Civil Service.

\section{RELATIONSHIP WITH MINISTER}

A matter considered crucial to many is the Ombudsman's impact upon the traditionally sacrosanct institution of ministerial responsibility. Permanent heads were asked:

"What effect has the Ombudsman had on your relationship with your minister?"

\begin{tabular}{ccc} 
None & Slight Effect & Total \\
\hline $79 \%(15)$ & $21 \%(4)$ & $100 \%(19)$
\end{tabular}

Several replies were quite interesting, and it was often apparent that the subject had never been thought of. Supplementary questions probed into various aspects of the relationship, especially whether they might have become more careful in their advice to their ministers. One carefully thought out negative reply was:

No, I don't worry about the Ombudsman. I give the minister the various options, but still make a firm recommendation. Of course, I take his preferences into account, but the Ombudsman doesn't figure in. We have mentioned the Ombudsman probably two or three times since 1962, but we have never discussed any specific case.

Another commented that there had been no effect, but that just yesterday in discussing a difficult case his minister had 
said, "I wish he'd take this to the Ombudsman and get it off our plates." Some of the respondents were defensive, as if the question suggested that they might let illegitimate factors influence their advice.

In a different vein, a head of an important but not very "political" department said, "My time with my minister is extremely limited. We wouldn't spend it talking about the Ombudsman." A very "political" colleague agreed that the Ombudsman had had no effect on his relationship with the minister, but added,

I can get very annoyed with the Ombudsman, of course. I worry about to what extent he can go into a case and my advice and the minister's decision. I don't know how far he can go and don't think he does either. He has such wide powers. Even so, I would never think of getting a direction from my minister; that would be wrong in principle.

Although four of the group felt the Ombudsman had had some effect on their relation with their minister, only two gave any indication that the effect might be in the direction of weakening the aura of trust and responsibility which is supposed to be the key to that relationship. One of them said, "Once or twice we have been quite annoyed. He evades his jurisdiction and examines the minister's decision by looking at our advice. We think he has made some mistakes and that it is our duty to fight back."5

A radically different effect was mentioned by a colleague who at first denied any impact:

I have asked the Minister to put something in writing to put it out of the Ombudsman's reach so he couldn't investigate it. Right now I can't think of an example, but it has happened once or twice.

Only one mentioned using this as a ploy to gain immunity from the Ombudsman. More of them specifically said that no such effect had resulted. Finally, one highly respected officer 
mentioned an interesting possibility that was not expressed by any of the others:

What worries me is the right of the Ombudsman to examine the department's advice to a minister. This doesn't worry me because of the possibility of exposing departmental machinations, but because sometimes ministers' decisions are made against departmental advice. I think it would be damaging to democracy if the public were to know (say, in the case of a tragedy) that in order to cut costs the minister made a technical decision against the advice of his experts in the field.

\section{EFFECTS UPON DEPARTMENT'S POLICIES}

The following item requested:

$$
\begin{aligned}
& \text { "What effect has the Ombudsman had on your } \\
& \text { department's policies?" }
\end{aligned}
$$

\begin{tabular}{ccc} 
Some & None & Total \\
\hline $32 \%(6)$ & $68 \%(13)$ & $100 \%(19)$
\end{tabular}

Although almost one-third agreed that the Ombudsman had had an effect upon their department's policies, in almost every case that agreement was halting. For example, one replied:

None, the cases he has taken up have been predominantly sort of personal cases. No.... There was one thing that could be called policy that we changed as a result of his investigation. Another one may have seemed to have changed. On another we made sure that the ruddy politicians understood the reasons for our policy.

Another permanent head admitted that the Ombudsman had had an effect on "some details, some inconsistencies in minor regulations." He added, "The Ombudsman's inquiries have sharpened us up on a few things. These things he forces 
us to rethink are minor, but still those small matters are important." From the other point of view, a new permanent head retorted, "No. None whatever. Very definitely not!" A more experienced colleague replied, "No, we have varied our decisions and made exceptions for him, but I don't think he has clean-bowled us yet (but you aren't a cricketer)." Most simply contended that there had been no effect on policy matters.

\section{DEPARTMENTAL MEMORANDA ON OMBUDSMAN}

Another item designed to measure a specific impact was:

"Have any special directives on the Ombudsman gone out in this department?"

\begin{tabular}{ccccc} 
No & Yes & $\begin{array}{c}\text { Don't } \\
\text { Know }\end{array}$ & $\begin{array}{c}\text { Not } \\
\text { Asked }\end{array}$ & Total \\
\hline $36 \%(7)$ & $32 \%(6)$ & $16 \%(3)$ & $16 \%(3)$ & $100 \%(19)$
\end{tabular}

Seven replied no, and some of these were defensive about the suggestion that it was possible that something should be so seriously wrong in their department that internal comment should be necessary. One replied tersely, "Quite clearly, no!" A colleague agreed, "No! I deliberately do not use him as a bogyman. I have good people in my department and don't need to scare them." However, six (as would be expected, four were high interactors.) reported that they had sent memoranda to their staff as a result of the Ombudsman's investigations-memoranda on such matters as recording telephone conversations and speeding the flow of correspondence. One confided, "I did use the Ombudsman to get my people to answer their mail quickly. I told them you must have at least an interim reply to citizens within two weeks because if you don't they may complain to the 
Ombudsman or the Minister and that will give you more work." Three respondents professed not to know and said to ask their staff.

\section{EFFECT UPON DEPARTMENTAL STAFF}

Further attempting to measure the Ombudsman's departmental impact, I asked:

"What effect has the Ombudsman had on your staff?"

\begin{tabular}{cccc} 
None & $\begin{array}{c}\text { None, but } \\
\text { Aware of Him }\end{array}$ & $\begin{array}{c}\text { Somewhat } \\
\text { More Careful }\end{array}$ & Total \\
\hline $47 \%(9)$ & $21 \%(4)$ & $32 \%(6)$ & $100 \%(19)$
\end{tabular}

About half maintained that the Ombudsman's existence had made no difference to their staff. Several were quite defensive, as the following examples suggest, "We only work on the merits of the case. We don't work in terms of the Ombudsman." Another agreed and added that "It's only the chap who wants to get the last drop who complains to him." Four permanent heads felt that the Ombudsman made no real difference to their staff but that there was a general awareness of him. They talked of a general consciousness of him and of a psychological awareness.

Six of the officials thought the Ombudsman had had an effect such as the following:

It would be hard to prove, but the fact that your treatment of a specific case may now be scrutinized by an outsider is bound to have an effect. I'm not talking about a big effect-just being more careful to record other files and telephone calls and generally being more precise and meticulous. Our people don't lose any sleep over him.

One replied that he thought the Ombudsman had been useful in "keeping my bureaucrats in line," but the following 
balanced view is more representative: "He has probably had the effect of making some of the staff more careful about making decisions, especially people with technical training who were promoted to administrative positions. But on the rest of the staff he has made little difference."

It is important to note that none answered this question in terms of the Ombudsman having the stifling effect of making the staff more cautiously cling to established rules and procedures. Nor were increased paperwork and delay mentioned, although the administrative burden of replying to the Ombudsman was commented upon a few times in answering other questions.

\section{IMPACT UPON DEPARTMENTAL PUBLIC RELATIONS}

The final departmental effect question was, "What effect has the Ombudsman had on your relationships with the public?" Seventy-five percent (fourteen) did not perceive any effect from the Ombudsman. The following statement would probably be subscribed to by the majority: "We figure that we have at least four million face-to-face contacts with the public each year. The Ombudsman would be brought into an infinitesimally small number of them." The five who perceived that the Ombudsman had an effect upon their relationships with the public were all high interactors, and all saw the Ombudsman as helpful to public relations! One dissenter exalted, "He puts us in the clear so often and tells our toughest customers to stop grizzling that I wouldn't stop people from complaining if I could." Echoing a similar sentiment, a colleague speculated, "This is pure guesswork, but the Ombudsman has good press coverage and, since most of our complaints are not upheld, this probably helps our image." It seems highly significant that none of the respondents expressed the view that the existence of the Ombudsman had acted as a magnet to draw out potential complainants and increase bothersome work. 


\section{EFFECTS UPON OTHER DEPARTMENTS}

In addition to measuring the Ombudsman's impact upon their own department, the following question was posed: "Aside from your own department, what do you feel has been the overall impact of the Ombudsman on the public service?" Five of them claimed to have no knowledge about what went on in other departments-particularly with regard to something as esoteric as the Ombudsman. A representative comment from those is, "I don't know that I've heard anyone else mention him; he just causes letter-work." Only one asserted that he had no effect, and it is significant to observe that only one indicated that he felt that the Ombudsman had made some civil servants overly cautious. The remainder thought they perceived-albeit dimly-some positive consequences. Four thought, in the words of one, that his effect has been "to show that he was not needed. He does cause us a lot of work. But I suppose he may be useful for some other departments." The largest single number, eight, suggested some effect on decision-making. One commented, "It's a hard question, but perhaps with your decision there's a note of additional care; it's a negative role." A colleague commented more positively, "It's a good experiment; he keeps the departments on their toes and counters the tendency toward arbitrary decisions which may adversely affect citizens. The public servant always has the notion that he is there."

\section{EVALUATION OF THE OMBUDSMAN'S JURISDICTION}

The data in Table 1 record the responses of the permanent heads to four attitude questions on the Ombudsman's jurisdiction. $^{6}$ The first was stated rather boldly, and it appeared that most of them felt that the Ombudsman's truncated jurisdiction did not prevent him from doing "a lot more good." It might be hypothesized that civil servants 
TABLE 1

DEPARTMENT HEADS' RESPONSES TO ATTITUDE

STATEMENTS ON OMBUDSMAN'S

JURISDICTION (n = 19)

\begin{tabular}{|c|c|c|}
\hline \multirow[b]{2}{*}{ Statement } & \multicolumn{2}{|c|}{ Mean for Interactors } \\
\hline & High & Low \\
\hline $\begin{array}{l}\text { 1. "Many complaints to the Ombudsman are } \\
\text { rejected on technical grounds; he could do a } \\
\text { lot more good if he had wider powers." }\end{array}$ & 5.1 & 4.1 \\
\hline $\begin{array}{l}\text { 2. "The Ombudsman should be able to investi- } \\
\text { gate the actions of Ministers as well as civil } \\
\text { servants' recommendations to them." }\end{array}$ & 5.7 & 4.3 \\
\hline $\begin{array}{l}\text { 3. "It would be better if the British system of } \\
\text { filtering complaints to the Ombudsman } \\
\text { through Members of Parliament were } \\
\text { adopted in New Zealand."a }\end{array}$ & 5.7 & 5.1 \\
\hline $\begin{array}{l}\text { 4. "The Ombudsman's powers should be re- } \\
\text { duced as in Britain where he only has juris- } \\
\text { diction over maladministration, not discre- } \\
\text { tionary decisions." }\end{array}$ & 4.3 & 4.1 \\
\hline $\begin{array}{l}\text { Key: } \\
\text { Agree strongly }=1 \\
\text { Midpoint }=3.5 \\
\text { Disagree strongly }=6\end{array}$ & & \\
\hline
\end{tabular}

a. Two "Don't know" responses to this statement are excluded from the analysis.

would resent the apparent discrimination the Ombudsman's Act prescribed in which their advice to the minister but not his decisions could be investigated. However, there was little agreement that the Ombudsman should be given the additional jurisdiction! It seems that their perception of the proper constitutional roles outweighed thoughts of personal advantage. Not a single respondent agreed that it would be desirable to filter complaints through Members of Parliament, and the rate of disagreement was the strongest of the four questions. Finally, there was disagreement that, like the British Ombudsman, theirs should be stripped of a large part of his powers by removing discretionary decisions from his 
jurisdiction. This seems to be an important indicator of his acceptance in the system.

Thus, the permanent heads were unwilling to accede to any of the proposed alterations of the Ombudsman's jurisdictions. What is most apparent from the table is that in each case the high interactors disagreed more strongly than the low group. Their consistency in opposing not only expansions, but also contractions-in spite of their greater experience-is striking and indicative of positive affect for the Ombudsman.

\section{GENERAL AFFECT FOR THE OMBUDSMAN}

Table 2 contains the responses to seven statements designed to probe the parameters of department heads' attitudes toward the Ombudsman. Disagreement with the first, which advocated Parliament's keeping a closer watch on the Ombudsman, was quite strong-mean $=4.95$ for the entire group. That high rate of disagreement and the even slightly higher one for the next item, which accused the Ombudsman of empire-building, at least indicated that the department heads did not perceive the Ombudsman as a dangerous intruder in their midst. In spite of occasional threats from civil servants about repetitious work caused by the Ombudsman, there was disagreement with the description of the Ombudsman's complainants as "quarrelsome people with no real complaint."?

The strongest rate of disagreement came in response to the fourth item, that the Ombudsman was too foreign for New Zealand. Nevertheless, it is clear from the mean for item five that department heads believed that the Ombudsman was transferred from Scandinavia and was not "basically a native product." The means for this statement reflect by far the greatest split between high and low interactors. Probably viewing the Ombudsman as a "foreigner" was a way of displacing frustrations created by their frequent interaction. 
TABLE 2

DEPARTMENT HEADS' MEAN RESPONSES

TO OMBUDSMAN ATTITUDE STATEMENTS $(n=19)$

Mean for Interactors

\section{Statement}

High Low

1. "Parliament should supervise more closely the work of its Parliamentary Commissioner."a

2. "The Ombudsman himself is an empire-builder who is trying to improve his position by getting $h$ is name before the people in press releases and speeches."

3. "A high percent of those who go to the Ombudsman are quarrelsome people with no real complaint."

4. "The Ombudsman is basically a foreign institution that does not fit into New Zealand's traditions."

5. "Though the name was borrowed from Scandinavia, New Zealand's Ombudsman is basically a native product."

6. "Though the parties differ somewhat on the ideal limits of the Ombudsman's jurisdiction, the institution is not a party matter."

7. "Knowledge of the presence of the Ombudsman acts as a sort of 'conscience' over the actions of the civil service."

Key

Agree strongly $=1$

Midpoint $=3.5$

Disagree strongly $=6$

a. One "Don't know" response to these statements is excluded from the analysis.

It also seems surprising that the permanent heads would so strongly refuse to identify the Ombudsman as a partisan matter. The fact that they do not may mean that they act as if it is a permanent institution that must be reckoned with rather than an ephemeral one. (The National Party, which instituted the Ombudsman, has held power continually since then.) However, they only slightly agreed that the Ombudsman acted as their conscience. Taking into account the 
defensiveness reported in responses to earlier questions, an even stronger response had been expected. Considering item five as somewhat of an exception, the table offers striking evidence of the attitudinal agreement between the high and low interactors. The mean deviation between the two groups on all seven statements is only . 4 of a scale point.

The department heads' ordering of the Ombudsman attitude statements listed in Tables 1 and 2 can also be usefully analyzed in another fashion. It is possible to analyze all eleven statements in the two tables on an internal basis, using measures of dispersion. The eleven statements were designed to reveal a coherent set of attitudes about the Ombudsman, and they are here interpreted as a proOmbudsman index.$^{8}$ Each department head's answers on the eleven items were simply totaled without weighting; the mean was found, and that number became his index score.

Thus, in order to score most favorably on the index (one would be the most pro-Ombudsman score possible and six the most anti-Ombudsman), the respondent would have to consistently and strongly favor the extension of the Ombudsman's jurisdiction, oppose its limitation, oppose Parliament's closer supervision, defend the Ombudsman's attraction of publicity, underscore his domesticity, defend the genuineness of the complainants' grievances, emphasize the Ombudsman's independence of party politics, view him as a conscience over the bureaucracy, and endorse his success in becoming integrated into New Zealand politics.

The requirements of the above list are so demanding that one would not expect even extreme advocates of the Ombudsman to place each statement in the most proOmbudsman position; but, in the result, there was one perfect score. Likewise, it would be surprising if even the Ombudsman's most adamant opponent were strongly opposed to him on every statement; hence, at the other end of the range, the most anti-Ombudsman score was only 4.0-two 
full scale points below the maximum. The mean pro-Ombudsman index score for permanent heads was 2.86. This relatively favorable score confirms the earlier pattern of responses on individual questions. Only three permanent heads-all of whom were high interactors-had scores over 3.5 , so that they would be counted as anti-Ombudsman.

There are differences between the index scores (3.1 and 2.6 respectively) of the high and low interactors. This difference seems to be a real one, although it is not possible to denote statistical significance to it. This finding is supported by the following correlation: First, the nineteen departments were ranked from highest to lowest in terms of actual interaction with the Ombudsman. Then this rank was compared with the permanent head's score on the proOmbudsman index. For comparison purposes, rankings on the index scores were from most anti-Ombudsman to most pro-Ombudsman. Using Spearman's rho, the coefficient of rank correlation was $.4 .^{10}$ Thus, there is a positive relationship that appears to be moderately strong between interaction and decreased affect for the Ombudsman. Of course, these data do not prove causation, but they-along with the other results and impressions-lead in that direction. Certainly we have a stronger justification for this assumption than that usually assumed in the popular saw, "Propinquity breeds contempt."

\section{CONCLUSIONS}

This investigation of the qualitative ${ }^{11}$ aspects of interaction between New Zealand's bureaucrats and the Ombudsman has revealed that department heads generally share positively affective orientations toward the Ombudsman. The investigation has been a particularly interesting one, because its context includes shared norms, but ambiguous authority. To the extent that we have measured the department heads' 
social distance from the Ombudsman, it is at least clear that he is not considered a pariah. Few felt that the Ombudsman had had any appreciable-much less a deleterious-effect upon the public service. While it is evident that there was no belief that the transfer of the Ombudsman had been a particular boon to the departments, it is highly significant that not one believed that it had been a great mistake. ${ }^{12}$ Clearly, the permanent heads were not preoccupied by the Ombudsman. There was, for example, no enthusiasm for either extending or curtailing his jurisdiction. However, it developed that many of them were "Ombudsman-conscious" when the need arose; the results of the pro-Ombudsman index showed that they harbored generally favorable attitudes toward the institution.

Affect for the Ombudsman tended to decrease as interaction with him increased. However, this decrease was relative; it must be recalled that only three of the nineteen scores extended into the anti-Ombudsman range. Considering the total characteristics of the permanent heads' perceptual relationships with the Ombudsman, they would be best described as respectful and responsive, if not enthusiastic and extensive. These New Zealand findings indicate that the introduction of an Ombudsman does not necessarily produce administrative conflict. Largely impressionistic Scandinavian research (Gellhorn, 1967; Hill, forthcoming) is corroborative. However, further comparative research into such Ombudsman systems as Tanzania's and incipient ones in the American states is necessary to attempt to determine what part of the Ombudsman's success is due to shared cultural factors and what part is explained by the institution's intrinsic nature.

\section{NOTES}

1. Since its invention in Sweden in 1809 , the institution of the Ombudsman has become au courant. It has been transferred to the foreign soils of Finland, 
Denmark, Norway, New Zealand, Guyana, Tanzania, Great Britain, Northern Ireland, the Canadian Provinces of Alberta, New Brunswick, and Quebec, and the American states of Hawaii and Nebraska. In addition, Ombudsman Bills have been introduced in most American state legislatures, a host of Ombudsmen operate on the local level, at least fifty Ombudsmen exist on the campuses of American colleges and universities, and similar officers have been proposed for large corporations, such as General Motors. See Anderson (1969) and Hill (forthcoming).

2. For general overviews of the New Zealand Ombudsman's entire operation see Gellhorn (1967: ch. 3) and Hill (1968).

3. The Ombudsman has been widely proposed in developing countries as an anti-corruption device. While this will be an interesting experiment, grounds exist for questioning whether an Ombudsman could by himself alter a system's established value pattern.

4. A subsequent question asking whether they recalled as particularly significant any of the Ombudsman's cases with other departments was met with blank stares. Not one of them was sufficiently interested to read about or comment upon other departments' cases.

5. The Ombudsman does not have jurisdiction over the ministers' independent decisions. He may, however, examine departments' recommendations to him.

6. The respondents were asked to rank each statement on a continuous scale from one (indicating strongly agree) to six (indicating strongly disagree). There was no middle or neutral category on the scale in order to allow the answers to be dichotomized, but in computing mean scores 3.5 would be the theoretical midpoint. Means above that point indicate disagreement, and those below indicate agreement of some extent or other.

The statements were printed on small cards and were handed to the respondents with the following introduction: "Now here are some statements that various M.P.'s and other people have made above government and politics in general. Would you please read each statement and place it on this agree-disagree scale where it belongs according to how much you agree or disagree with it." When he finished, the interviewer placed them in the properly marked pocket of an envelope for later recording and reshuffling. The procedure followed was similar to that described in Kilpatrick et al. (1964: ch. 2).

7. For an analysis of the complainants, see Hill (1971b).

8. The statements were arbitrarily determined to elicit basic orientations about the Ombudsman, and it is contended that they have considerable "face" validity. They were not scaled in the sense of a technique such as Guttman scaling.

9. The scores of the negatively stated items three and four of Table 1 and one through four in Table 2 were simply inverted.

10. The range for this statistic is from -1 to +1 (perfect negative correlation to perfect positive correlation). Zero indicates no association. The data do not satisfy the assumptions for tests of statistical significance.

11. On quantitative aspects of interaction, see Hill (1971a). 
12. The findings reported here appear not to be incongruent in significant respects to those reported in Weeks (1969). That article was primarily based upon mailed questionnaires sent out while the present research was under way.

\section{REFERENCES}

ANDERSON, S. V. (1969) Ombudsman Papers: American Experience and Proposals. Berkeley: University of California Institute of Governmental Studies.

DAHL, R. A. (1963) Modern Political Analysis. Englewood Cliffs, N.J.: Prentice-Hall.

GELLHORN, W. (1967) Ombudsmen and Others: Citizens' Protectors in Nine Countries. Cambridge, Mass.: Harvard Univ. Press.

GOODE, W. J. and P. K. HATT (1952) Methods in Social Research. New York: McGraw-Hill.

HILL, L. B. (forthcoming) Ombudsmen. New York: Oxford Univ. Press.

--- (1971a) "The ombudsman as administrative actor: a sociometric analysis of the New Zealand ombudsman's interaction with governmental departments and of the impact of his investigations." Presented at the annual meeting of the Southwestern Political Science Association.

--- (1971b) "Socio-psychological dimensions of complaints to ombudsmen: a New Zealand analysis." Presented at the annual meeting of the American Political Science Association.

- (1968) "The New Zealand Ombudsman's authority system." Pol. Sci. 20 (September): 40-51.

HOPKINS, T. K. (1964) The Exercise of Influence in Small Groups. Totowa, N.J.: Bedminster.

KILPATRICK, F. B., M. C. CUMMINGS, and M. K. JENNINGS (1964) Source Book of a Study of Occupational Values and the Image of the Federal Service. Washington, D.C.: Brookings Institution.

LASSWELL, H. D. and A. KAPLAN (1952) Power and Society. London: Routledge \& Kegan Paul.

PARSONS, T. (1968) "Social interaction," pp. 429-440 in the International Encyclopedia of the Social Sciences, Volume 7.

--- (1963) "Rejoinder to Bauer and Coleman." Public Opinion Q. 27 (Spring): 87-92.

WEEKS, K. M. (1969) "Public servants in the New Zealand ombudsman system."

Public Administration Rev. 28 (November/December): 633-638. 